\title{
RUTIN, A FLAVONOID PHYTOCHEMICAL, AMELIORATES CERTAIN BEHAVIORAL AND ELECTROPHYSIOLOGICAL ALTERATIONS AND GENERAL TOXICITY OF ORAL ARSENIC IN RATS
}

\author{
Kitti SÁrközi, András Papp, * Zsuzsanna Máté, Edina Horváth, \\ Edit PAulik and ANDrea Szabó \\ Department of Public Health, University of Szeged Faculty of Medicine, \\ Dóm tér 10, H-6720 Szeged, Hungary
}

(Received: May 5, 2014; accepted: June 23, 2014)

\begin{abstract}
Arsenic affects large populations and attacks, among others, the nervous system. Waterborne or occupational exposure causes electrophysiological alterations and motor disturbances in humans, and analogous effects were found in animals. Certain phytochemicals may be protective against As-caused damages. In the present study it was investigated whether the flavonoid rutin, applied via the drinking water $(2 \mathrm{~g} / \mathrm{L})$, ameliorates the effects of arsenic given by gavage $\left(10 \mathrm{mg} / \mathrm{kg}\right.$ b.w., in form of $\left.\mathrm{NaAsO}_{2}\right)$ on open field motility, evoked cortical and peripheral electrophysiological activity, and body weight gain in adult male Wistar rats. Body weight gain was significantly reduced from the $4^{\text {th }}$ week of the 6 weeks arsenic treatment and this effect was largely abolished by rutin in the combination treatment group. Rats treated by arsenic alone showed decreased open field motility; latency of the cortical evoked potentials increased and peripheral nerve conduction velocity decreased. These functional alterations were also counteracted by co-administration of rutin, and both the antioxidant and the chelating activity of rutin might have contributed to the ameliorative effect. These results are apparently novel and support the potential role of natural agents in preserving human health in a contaminated environment.
\end{abstract}

Keywords: Arsenic, neurotoxicity, rutin, antioxidant, rat

\section{INTRODUCTION}

High arsenic (As) content of drinking water, due mostly to geochemical conditions, has been causing mass oral As exposure in large populations. Drawing water from bedrock aquifers by deep tube wells, normally a very safe method of water supply, may release As bound to sedimentary rocks [7]. The problem used to affect the population in South-East Hungary and the adjacent Romanian and Serbian regions [4, 20] and remains a severe one in regions of Asia (Bengal Basin in India/Bangladesh: As levels up to 3,000 $\mu \mathrm{g} / \mathrm{L}$ ) and South America (Argentina: up to $10,000 \mu \mathrm{g} / \mathrm{L}$ ) [23].

Though the nervous system is not among the classical sites of attack of As [14, 29] quite a few published data indicate its neurotoxicity. High As in well water resulted in fatal acute poisoning due to encephalopathy, presenting with mental disorders and

\footnotetext{
*Corresponding author; e-mail address: papp.andras@med.u-szeged.hu
} 
finally coma [2]. In Bangladesh, notorious for mass As exposure as mentioned above, schoolchildren with elevated internal As load showed impaired fine motor control and body coordination [28]. Workers in a copper smelter, exposed by the arsenic content of the ore processed, showed alterations of the EEG patterns, visual evoked potentials, and peripheral nerve action potentials [13]. Such effects of As have also been modeled in animals [10, 33, 35].

In a public health problem of this magnitude, protection of the affected population is a primary concern. Besides technological solutions like removal of As from drinking water, it has been also described repeatedly that various phytochemicals - plantderived substances with a biological effect [34] - can be protective against As-caused damages. Ascorbic acid and alpha-tocopherol diminished mitochondrial damage and lipid peroxidation in As-exposed rats [3]; the same two antioxidants also reduced oxidative damage and cell death in vitro in rat and human fetal brain tissue [5]. Rutin, the phytochemical used in the present work, is found in a number of edible plants like buckwheat [18] or citrus fruits and rhubarb [9]. The bioavailability of rutin - or, more exactly, of its aglycone, quercetin which is responsible for the biological activities including antioxidation - is limited due to poor intestinal absorption and to degradation by the gut microflora both in humans and in experimental animals [9]. In spite of that, the neuroprotective effect of rutin has been documented in animal models of brain damage induced by streptozotocin [15] or ischemia [11]; and has been attributed mainly to antioxidant effect [25].

The aim of the present work was to see if the neurotoxic effect of subacute oral As exposure of rats, manifesting in behavioral and electrophysiological alterations, and some general toxic effects, can be ameliorated by simultaneous oral application of rutin.

\section{MATERIALS AND METHODS}

\section{Animals and treatment}

Young adult male Wistar rats, altogether 27, were obtained from Toxi-Coop (Budapest, Hungary). The animals were housed, with three rats in one cage, in a controlled environment animal house $\left(22 \pm 1{ }^{\circ} \mathrm{C}, 40-60 \%\right.$ relative humidity, $12 \mathrm{~h}$ light/dark cycle with light on at 06:00), and had free access to standard rodent chow and to water (local plain tapwater had ca. $7 \mu \mathrm{g} / \mathrm{L}$ arsenic content as stated by the municipal waterworks).

As seen in Table 1, the work involved a rutin-treated, an As-treated and a combined group (consisting of 9 rats each). An untreated control group was not used because it was shown in a previous experiment [32] that rutin alone had no noteworthy effect on the parameters investigated. Rutin was delivered via the rats' drinking water. Tapwater was boiled then allowed to cool under cover to reduce chlorine and oxygen content, rutin was added, and $\mathrm{pH}$ was first brought to ca. 9.5 with $\mathrm{Na}_{2} \mathrm{CO}_{3}$ to achieve complete dissolution of rutin then back to 7.5 with $20 \%$ food-grade acetic acid. This 
Table 1

Treatment groups and doses

\begin{tabular}{|l|c|c|c|}
\hline Treatment group & \multicolumn{1}{|c|}{ Rutin } & \multicolumn{1}{|c|}{ Arsenic } & \multicolumn{1}{c|}{ Arsenic + Rutin } \\
\hline \multicolumn{1}{|c|}{ Code } & Rut & \multicolumn{1}{c|}{ As } & \multicolumn{1}{c|}{ As + Rut } \\
\hline $\begin{array}{l}\text { Dose and } \\
\text { administration }\end{array}$ & $\begin{array}{l}\text { Rutin, } 2 \mathrm{~g} / \mathrm{L} \text { in the } \\
\text { drinking water }\end{array}$ & $\begin{array}{l}\text { As, } 10 \mathrm{mg} / \mathrm{kg} \text { b.w., by gavage } \\
(8.67 \mathrm{mg} / \mathrm{ml} \mathrm{NaAsO} \text { in } \\
\text { distilled water, } 2 \mathrm{~mL} / \mathrm{kg} \text { b.w. })\end{array}$ & $\begin{array}{l}\text { As, } 10 \mathrm{mg} / \mathrm{kg} \text { b.w., by gavage } \\
+ \text { rutin, } 2 \mathrm{~g} / \mathrm{L} \text { in the drinking } \\
\text { water }\end{array}$ \\
\hline
\end{tabular}

solution was changed to fresh one every two days. Antioxidant capacity of the fresh solution was $0.49 \pm 0.08 \mathrm{mg}$ ascorbic acid equivalent per $\mathrm{ml}$ (measured by FRAP) and did not significantly change in 48 hours. For As administration, $\mathrm{NaAsO}_{2}$ was dissolved in distilled water, and was given by gavage, once daily, 5 days per week, for 6 weeks. See Table 1 for groups and doses (dose of As and the treatment time were identical to that used and found effective in another study on As and possible herbal protective agents [31], and the dose of rutin was set to obtain an antioxidant activity in the drinking fluid comparable with that in the mentioned study). The chemicals, except acetic acid, were from Sigma-Aldrich Hungary (Budapest).

\section{General toxicology}

During treatment, body weight gain of the rats, and consumption of food and water, was daily measured. Daily animal care included also observation and recording of any signs of toxicity (e.g. rough fur, hunched back, unusual aggressive behavior).

At the end of electrophysiological recording (see below) the rats were sacrificed by an overdose of urethane, and were dissected. For As level determination, 3 animals were randomly chosen from each group. Of these animals, cerebral cortex, liver, kidney and blood were quickly frozen in liquid nitrogen and stored at $-20^{\circ} \mathrm{C}$. For the measurement, samples were dried at $80^{\circ} \mathrm{C}$ to constant weight, and were digested in $65 \% \mathrm{HNO}_{3}\left(4 \mathrm{~mL} / \mathrm{g}\right.$ wet tissue) at $90{ }^{\circ} \mathrm{C}$ for $90 \mathrm{~min}$. Arsenic determination was done, from a dilution of the digested matter, by inductively coupled plasma mass spectrometry at the Department of Inorganic and Analytical Chemistry, University of Szeged, Faculty of Science and Informatics, Szeged, Hungary.

\section{Open field behavioral investigation}

The rats' spontaneous motility was tested in an open field (OF) apparatus (Conducta 1.3 System; Experimetria Ltd., Budapest) immediately before and after the 6 weeks treatment period. The OF box used was of $48 \times 48 \times 40 \mathrm{~cm}$ size and was equipped with two arrays of infrared beam gates at floor level and at $12 \mathrm{~cm}$ height. The animals were put into the centre of the OF box one by one for a 10 min session. From the beam 
interruptions caused by the rat moving around, event counts and summed time of the basic activity forms (ambulation, local activity, rearing, immobility), as well as run length of ambulation, were computed as follows: more than $40 \mathrm{~mm}$ shift in the location of interrupted beams at the floor level during a time unit of $1 \mathrm{~s}$ was interpreted as ambulation; less shift, as local activity; and no shift at all, as immobility. Rearing was recorded if beams at floor level and higher level were interrupted simultaneously. In earlier works of us [37] this method was found sensitive to metal-induced changes of motor activity.

\section{Electrophysiological investigation}

On the day following the last week OF session, the rats were anesthetized with urethane $(1000 \mathrm{mg} / \mathrm{kg} \mathrm{b.w.} \mathrm{ip.} \mathrm{[21])} \mathrm{and} \mathrm{were} \mathrm{prepared} \mathrm{for} \mathrm{electrophysiological} \mathrm{record-}$ ing. The left hemisphere was surgically exposed (lidocaine spray was applied on the wounds) and spontaneous electrical activity (electrocorticogram, ECoG) was recorded from the primary sensory areas (somatosensory, SS; visual, VIS; and auditory, AUD) for 6 minutes using ball-tipped silver wire electrodes placed directly on the dura. From this, band spectrum according to the standard human EEG bands (delta, 0.5-4 Hz; theta, 4-7 Hz; alpha, 8-13 Hz; beta1, 13-20 Hz; beta2, 20-30 Hz; gamma, $30-50 \mathrm{~Hz}$ ) [17] was calculated.

Then, evoked potentials (EPs) were recorded from the same sites. Somatosensory stimulation was done by square pulses (3-4 V; $0.05 \mathrm{~ms} ; 1,2$ and $10 \mathrm{~Hz}$ frequency) delivered through a pair of needles inserted into the contralateral whiskery skin. Visual stimulation was performed by flashes $(1 \mathrm{~Hz})$ of a high-luminance white LED placed to the contralateral eye of the rat. For acoustic stimulation, clicks $(1 \mathrm{~Hz})$ were applied to the contralateral ear through the hollow ear bar of the stereotaxic frame. The stimuli were applied in trains of 50. Latency and duration of the EPs was measured after averaging. From the tail nerve, compound action potential (CAP) was recorded by inserting a pair of needle electrodes at the base of the tail for stimulation, and another pair $50 \mathrm{~mm}$ distally for recording. Conduction velocity was calculated from this distance and the onset latency of the nerve action potential. Relative refractory period was measured by double stimuli with 1-10 ms inter-stimulus interval, from the extra delay of the second potential. The complete electrophysiological work was performed by means of the software Neurosys 1.11 (Experimetria Ltd., Budapest, Hungary). For further details of the methods, see [26].

During the whole study, the principles of the Ethical Committee for the Protection of Animals in Research of the University were strictly followed. The methods used in this work were licensed by the authority competent in animal welfare issues under No. XXI./02039/001/2006. 

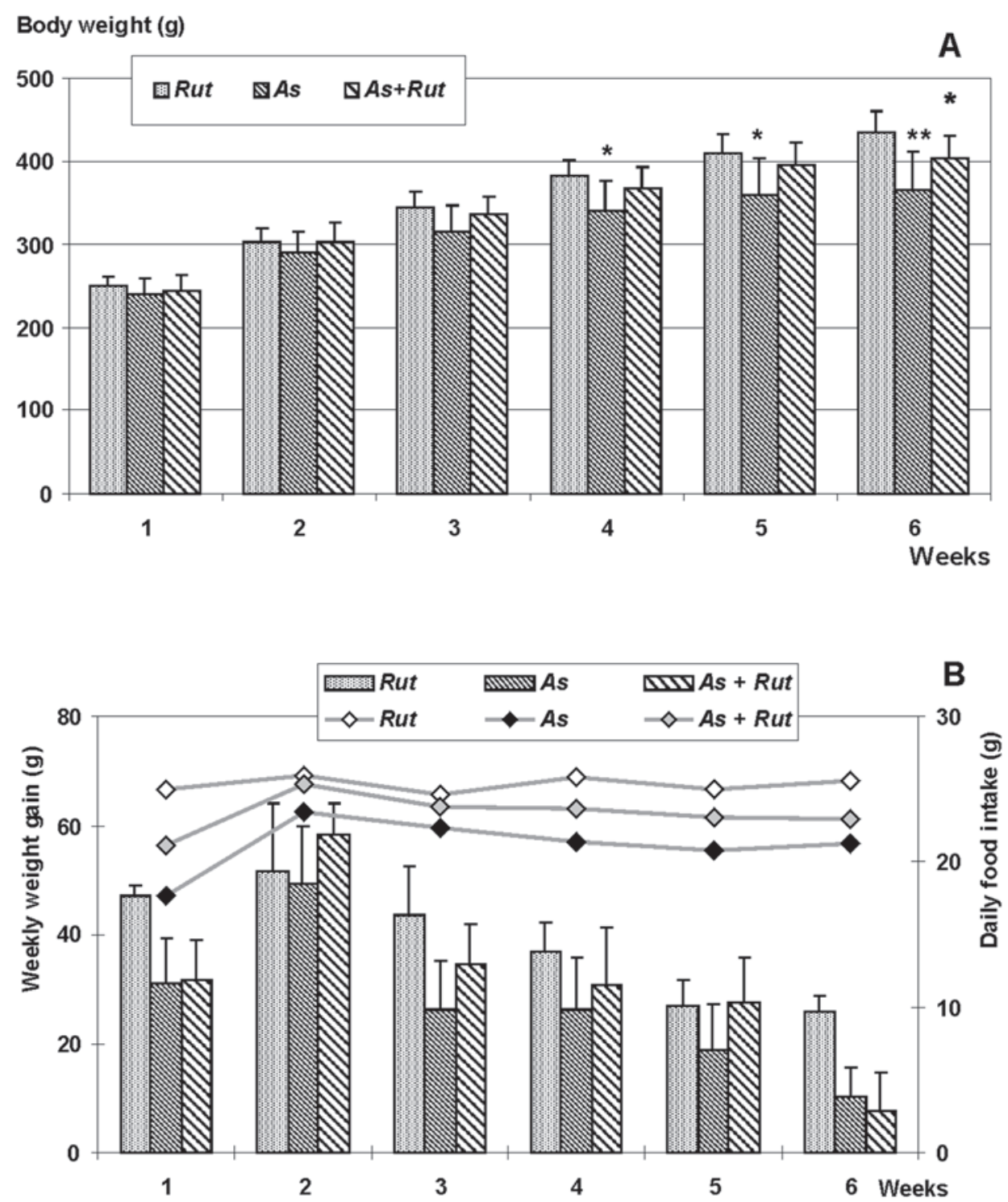

Fig. 1. The effect of arsenic and rutin treatment on the rats' body weight. A) Body weights measured on Friday of treatment weeks 1 to 6 (mean + SD, $n=9$ ). ${ }^{*},{ }^{* *} \mathrm{p}<0.05,0.01$ vs. Rut. B) Weekly average body weight gain (bar graph; mean $+\mathrm{SD}, \mathrm{n}=9$ ) and weekly average of daily food consumption (line graph; mean, $\mathrm{n}=9$ ) 


\section{Data processing}

Group differences were analyzed by one-way ANOVA and post hoc Scheffe's test, with $\mathrm{p}<0.05$ as limit of significance. The possible linear correlation between data sets was tested by the "linear fit" function of MS Excel. This function uses the least squares method to fit a straight line to the measurement data, and examines the strength of relationship with Fisher's F test.

\section{RESULTS}

\section{General toxicity}

A difference in mean body weight between group Rut and As appeared in the $3^{\text {rd }}$ week and became significant $(\mathrm{p}<0.05)$ from the $4^{\text {th }}$ week on (Fig. 1A). Weight gain in the combination group (As + Rut) was nearly as strong as in Rut and decreased significantly only by the last week. The weekly weight gain data had similar trend except in the first week where group As and As + Rut were equally affected (Fig. 1B). This graph also shows that the weekly averages of daily food intake and of weight gain were not in parallel, suggesting that food intake probably cannot explain the body weight differences. It was also observed during daily care that rats in group As were more irritable and aggressive than others.

The total intake of As and rutin, and the resulting tissue As levels, are shown in Table 2 .

Table 2

Calculated total external doses of As and rutin, and measured internal As levels

\begin{tabular}{|l|l|c|c|c|}
\hline \multicolumn{2}{|c|}{ Treatment group } & Rut & As & As+Rut \\
\hline $\begin{array}{l}\text { Total arsenic and/or rutin intake } \\
\text { during the 6 weeks treatment } \\
(\mathrm{mg} / \mathrm{rat})\end{array}$ & $848.4 \pm 216.3^{1}$ & $92.08 \pm 16.772$ & $\begin{array}{c}99.04 \pm 18.60 \text { (As) } \\
832.5 \pm 327.1 \text { (rutin) }\end{array}$ \\
\hline $\begin{array}{l}\text { Internal arsenic load } \\
\text { after 6 weeks } \\
\text { treatment }(\mu \mathrm{g} / \mathrm{kg} \text { dry } \\
\text { tissue weight) }\end{array}$ & Blood & $14420.9 \pm 1343.2$ & $1565127.5 \pm 53422.9^{* * *}$ & $1385852.7 \pm 99526.4^{* *}$ \\
\cline { 2 - 5 } & Cortex & $1053.9 \pm 699.5$ & $71767.4 \pm 17716.1^{* *}$ & $29561.1 \pm 9149.1^{*}$ \\
\cline { 2 - 5 } & Liver & $143.9 \pm 117.9$ & $27992.7 \pm 5868.2^{* *}$ & $9493.5 \pm 3093.7^{*}$ \\
\cline { 2 - 5 } & Kidneys & $620.8 \pm 361.4$ & $388945.7 \pm 62458.8^{* *}$ & $390643.4 \pm 54041.3^{* *}$ \\
\hline
\end{tabular}

Mean \pm SD, $\mathrm{n}=9$ (total external dose) or $\mathrm{n}=3$ (internal level).

$*, * *, * * * \mathrm{p}<0.05,0.01,0.001$ vs. Rut

\#p $<0.05$ vs. As + Rut

${ }^{1}$ Calculated from the daily water consumption data.

${ }^{2}$ Calculated from the daily doses based on actual body weights. 


\section{Open field behavior}

Before treatment, the time share of the four basic form of OF activity (ambulation, local activity, immobility, rearing) was similar in the three groups (Fig. 2). Following the 6 weeks exposure by the test substances, local activity and immobility increased (vs. week 0) in group As, but not in Rut and As + Rut. Rearing in week 6 was higher than in week 0 in all three groups but less in group As than in those receiving rutin. Taken together, these differences indicated decreased motility of rats in group As.

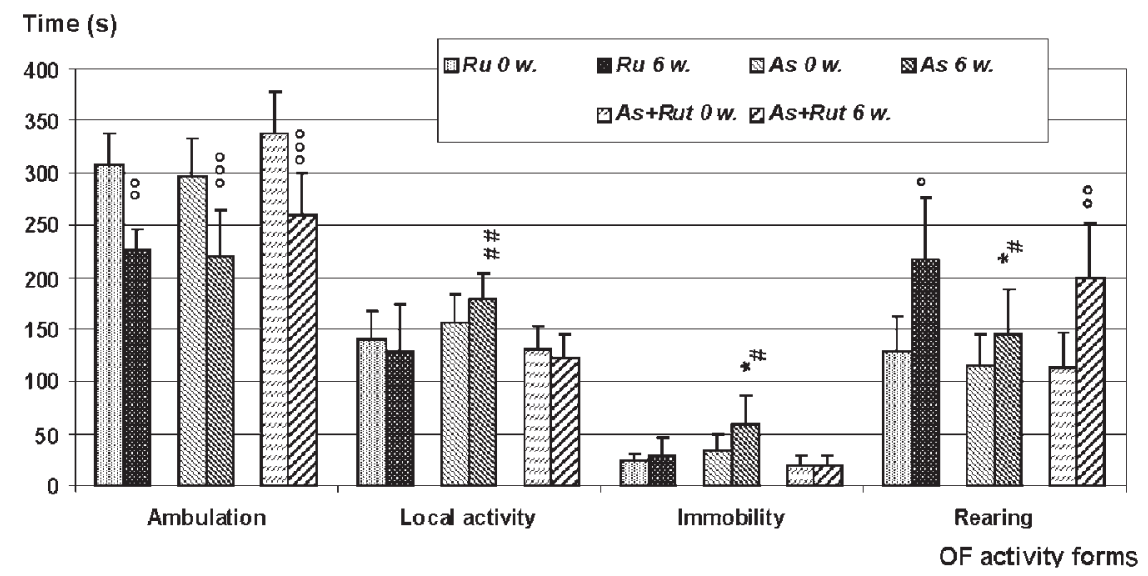

Fig. 2. Effects of the open field behavior. Time spent by the rats in various forms (see abscissa) of OF

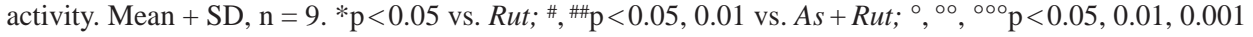
week 6 vs. week 0 within the treatment group

\section{Electrophysiology}

ECoG band power spectrum was not significantly different among the treatment groups. The measured data of evoked activity, on the contrary, indicated slowed reaction of As-treated rats on external stimulation.

As seen in Fig. 3, latency of the EPs in all three modalities increased significantly in group As vs. Rut, but in the combination group As + Rut this effect was largely abolished. Also, the frequency-dependent lengthening of SS EP latency was stronger in As than in Rut and As + Rut, the ratio of mean latencies with $10 \mathrm{~Hz} v$ v. $1 \mathrm{~Hz}$ stimulation being 1.061 in group Rut, 1.092 in As; and 1.060 in As + Rut. The changes in the duration of EPs were similar but less clear-cut (not shown).

In accordance with the changes in the cortical responses, CAP of the tail nerve showed significantly decreased conduction velocity in group As - and to a lesser extent also in As + Rut, but the As + Rut vs. As difference was significant also (Fig. 3). Relative refractory period was lengthened in group As but not in As + Rut. 

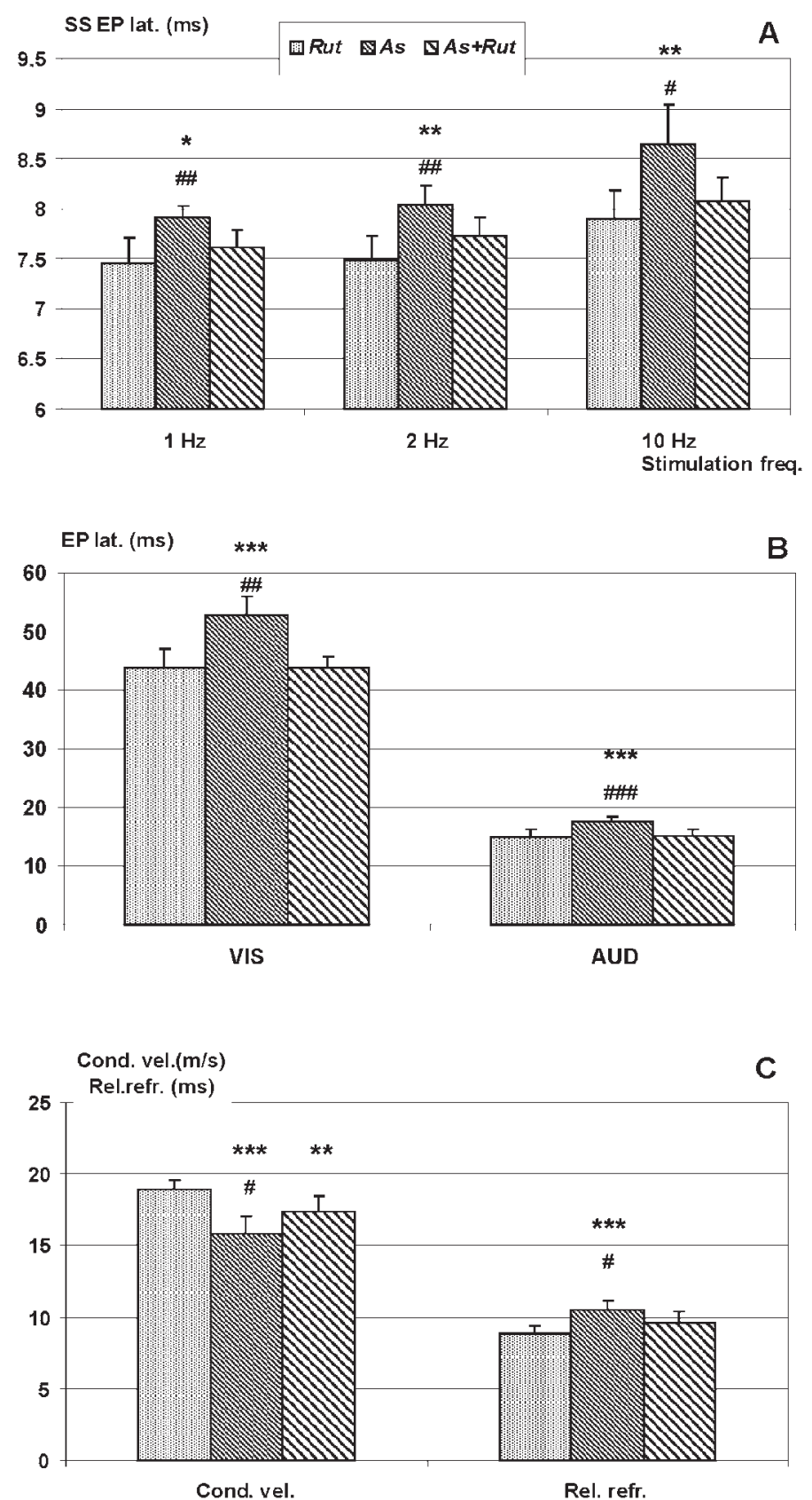

Fig. 3. Effects on the cortical and peripheral evoked activity. A) latency of the somatosensory EPs recorded with three stimulation frequencies; B) latency of the visual and auditory EPs; C) conduction velocity and relative refractory period of the tail nerve. Mean $\pm \mathrm{SD}, \mathrm{n}=9 .{ }^{*}, * *, * * * \mathrm{p}<0.05,0.01,0.001$ vs. Rut; \#, \#\# $<0.05,0.01$ vs. As + Rut 
KITTI SÁRKÖZI et al.

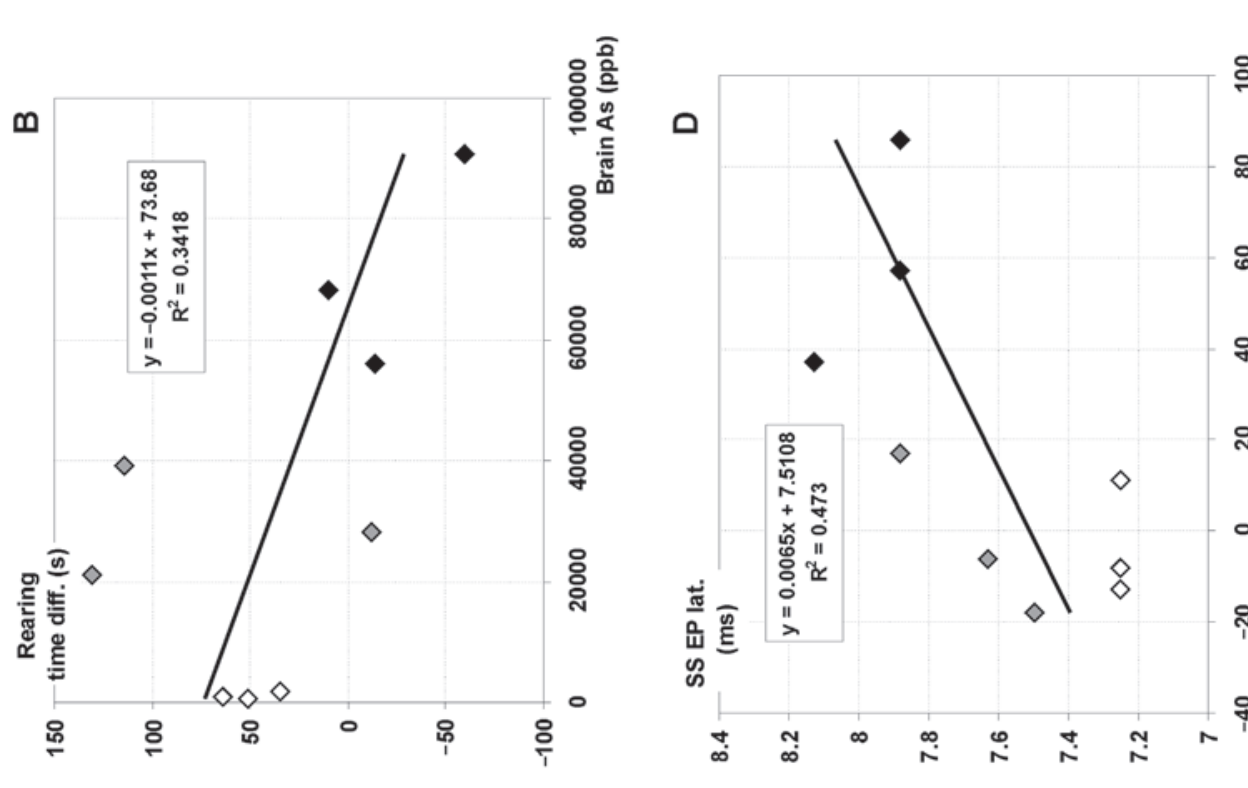

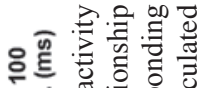

整 踏

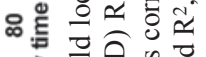

产它产

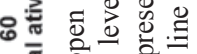

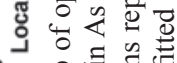

\& 영

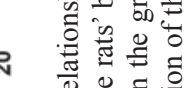

- 0 员言焉

400

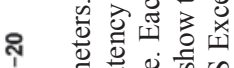

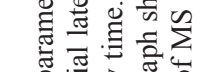

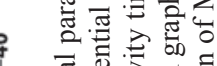

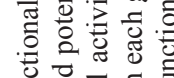

으을

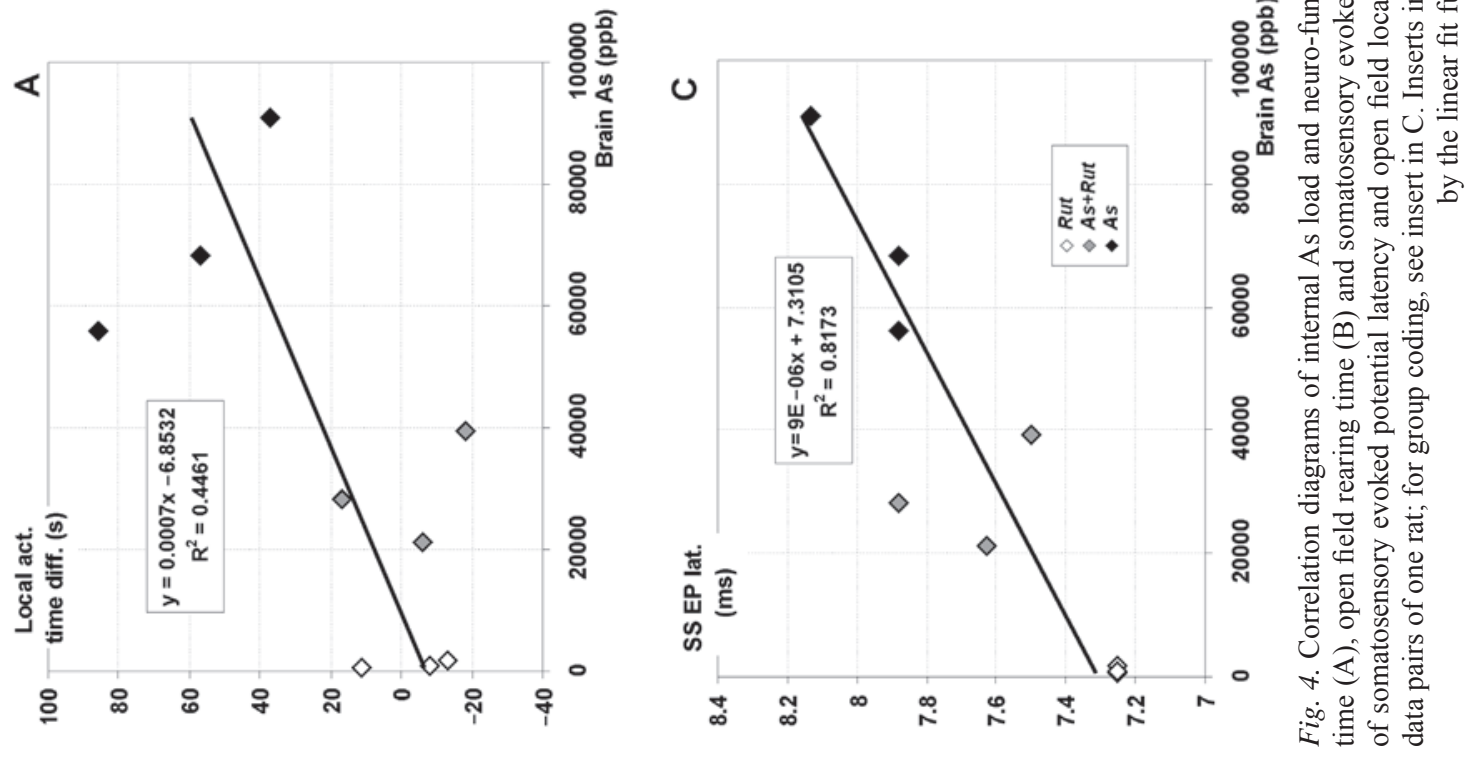

Acta Biologica Hungarica 66, 2015 
The relationship of internal As load and functional changes, suggested by the results presented above, was further investigated by testing linear correlation. In Fig. 4, the animal-by-animal individual values of the change (week 6 vs. week 0 ) in local activity and rearing (panels A and B, respectively) and of SS EP latency (C) are shown against the corresponding brain As levels; while in panel D, correlation between two of the mentioned functional parameters is shown. The graphs show a fair linear correlation, supporting the causal role of As. Beyond that, in graphs A, B and $\mathrm{C}$ one can see that, in spite of the identical external As load, in rats of group $A s+R u t$ not only the functional parameters were less affected than in group As but the internal load (brain As level) was also lower. Data in Table 2 also show that although the external As load in groups As and As + Rut were nearly identical, the tissue As levels in the brain and liver samples of group As were ca. 3 times higher than in corresponding samples of group As + Rut.

\section{DISCUSSION}

Parallel oral administration of rutin could substantially diminish the functional neurotoxic effects and general toxicity of subacute arsenic exposure in rats - although the amounts of As applied to the rats by gavage caused massive internal load (shown by the As levels of the treated rats' organs, Table 2).

The significant effect of oral As on body weight towards the end of the treatment period and the partial reversal of the effect by simultaneous application of the antioxidant were both similar to that published in [38]. The time course of body weight gain was different in the three groups but their average food intake was nearly similar and stable in time (Fig. 1B), suggesting that the differences were more due to metabolic changes and not to dissimilar amounts consumed.

Changes in parameters of open field behavior and evoked nervous activity were congruent in indicating depressed activity of the central nervous system in the As-exposed rats. CNS damage in As-exposed humans has been described repeatedly (reviewed in [30, 36]) but corresponding electrophysiological changes have been mentioned only in a few papers. A single large dose of inorganic As caused complete and partial loss of VIS and AUD EPs, respectively, in a person attempting suicide [8]. In another study [19] lasting reduction of nerve conduction velocity and abnormal action potentials were seen in survivors of a single As dose. In [13] lengthened latency of the pattern reversal visual EPs and various peripheral nerve abnormalities more frequently observed in As-exposed workers of a copper smelter than in nonexposed control employees of the same factory. In As-exposed rats, slowed conduction velocity of the sural nerve, and massive deposition of As, was seen [10]. Also in rats, As load resulted in decreased OF motility [33, 38].

The nervous system effects observed in our work were in agreement with all that; and the correlation of these effects with internal As load (Fig. 4) also pointed to the causal role of As. These correlation plots, however, also showed that in group As + Rut not only the functional changes were milder than in group As but also the 
internal As load (level in the brain). From this it could be inferred that more than on mechanisms of action were involved in the protective effect of rutin against the toxic effects of As.

Oxidative stress - due among others to binding thiol-containing antioxidants, liberating iron from ferritin, and uncoupling oxidative phosphorylation [16] - plays a major role in the toxicity of As, and biochemical signs of oxidative stress were indeed found in exposed humans [13] and in animal experiments [38]. Rutin, on the contrary (together with related flavonoids) is known to exhibit antioxidant activity [25]. On a human dopaminergic cell line in vitro, rutin dose-dependently prevented ROS generation and apoptosis induced by rotenone [27]. In an in vivo rat model of Alzheimer's disease, rutin attenuated both cognitive impairment and biochemical indicators of oxidative stress [15]. Concerning human health, rutin was among the herbal agents suggested as potential ingredients in "neuroprotective functional drinks" [39].

The documented antioxidant action of rutin explains the amelioration of As-induced neuro-functional damage seen in the present study, taking into consideration the ability of As to cause oxidative stress [16] on one hand, and the vulnerability of the nervous system as a whole to oxidative damage on the other, resulting from high intensity of mitochondrial energy production, abundance of (unsaturated) structural lipids, and to limited antioxidant capacity [12]. Oxidative damage to membrane lipids may disturb the function of synapses and receptors [6], leading finally to functional alterations at higher levels (such as macro-electrophysiology and behavior).

The difference in internal As load in rats from group As vs. As + Rut (Table 2, Fig. 4) could result from dissimilar rate of intake and/or elimination of As but - given that As was administered, in amounts calculated exactly for each animal, by gavage - the latter is more likely. Both rutin, and its aglycone quercetin, were shown to act as chelators to bind transition metal ions and reduce oxidative load this way [1, 24]. In As-exposed mice, quercetin enhanced the removal of As from its target organs [22], beyond reducing oxidative stress in the liver. Based on the near-complete reduction of the As-induced neuro-functional alterations by rutin on the one hand, and the lower As level in the cerebral cortex samples of rats in group As + Rut compared to those in group As, it can be supposed that both the antioxidant effect and the chelating action of rutin had a role in diminishing nervous system damage of arsenic-exposed rats.

The protective effect of rutin against arsenic-induced neuro-functional alterations is apparently a new finding, and supports the potential role of natural agents in preserving human health in a contaminated environment.

\section{ACKNOWLEDGEMENTS}

This work was supported by the grants of the Hungarian-Romanian Intergovernmental S\&T Cooperation Program TÉT_10-1-2013-0019. The authors are thankful to Dr. Gábor Galbács and his colleagues (Department of Inorganic and Analytical Chemistry, University of Szeged Faculty of Science and Informatics, Szeged, Hungary) for measuring tissue As levels; and to Dr. Judit Krisch and her colleagues (Department of Food Engineering, University of Szeged Faculty of Engineering, Szeged, Hungary) for the FRAP measurements. 


\section{REFERENCES}

1. Afanasev, I. B., Dorozhko, A. I., Brodskii, A. V., Kostyuk, V. A., Potapovitch, A. I. (1989) Chelating and free radical scavenging mechanisms of inhibitory action of rutin and quercetin in lipid peroxidation. Biochem. Pharmacol. 38, 1763-1769.

2. Armstrong, C. W., Stroube, R. B., Rubio, T., Siudyla, E. A., Miller, G. B. Jr. (1984) Outbreak of fatal arsenic poisoning caused by contaminated drinking water. Arch. Environ. Health 39, 276-279.

3. Balakumar, P., Kaur, J. (2009) Arsenic exposure and cardiovascular disorders: An overview. Cardiovasc. Toxicol. 9, 169-176.

4. Börzsönyi, M., Bereczky, A., Rudnai, P., Csanády, M., Horváth, A. (1992) Epidemiological studies on human subjects exposed to arsenic in drinking water in Southeast Hungary (Letter). Arch. Toxicol. 66, 77-78.

5. Chattopadhyay, S., Bhaumik, S., Purkayastha, M., Basu, S., Chaudhuri, A. N., Das Gupta, S. (2002) Apoptosis and necrosis in developing brain cells due to arsenic toxicity and protection with antioxidants. Toxicol. Lett. 136, 65-76.

6. Coyle, J. T., Puttfarcken, P. (1993) Oxidative stress, glutamate and neurodegenerative disorders. Science 262, 689-695.

7. Duker, A. A., Carranza, E. J. M., Hale, M. (2005) Arsenic geochemistry and health. Environ. Int. 31, 631-641.

8. Fincher, R. M., Koerker, R. M. (1987) Long-term survival in acute arsenic encephalopathy. Follow-up using newer measures of electrophysiologic parameters. Am. J. Med. 82, 549-552.

9. Formica, J. V., Regelson, W. (1995) Review of the biology of quercetin and related bioflavonoids. Food Chem. Toxicol. 33, 1061-1080.

10. García-Chávez, E., Segura, B., Merchant, H., Jiménez, I., Del Razo, L. M. (2007) Functional and morphological effects of repeated sodium arsenite exposure on rat peripheral sensory nerves. J. Neurol. Sci. 258, 104-110.

11. Gomes Rodrigues, A. M., dos Santos Marcilio, F., Frazao Muzitano, M., Giraldi-Guimaraes, A. (2013) Therapeutic potential of treatment with the flavonoid rutin after cortical focal ischemia in rats. Brain Res. 1503, 53-61.

12. Guerra-Araiza, C., Alvarez-Mejia, A. L., Sanchez-Torres, S., Farfan-Garcia, E., Mondragon-Lozano, R., Pinto-Almazan, R., Salgado-Ceballos, H. (2013) Effect of natural exogenous antioxidants on aging and on neurodegenerative diseases. Free Rad. Res. 47, 451-462.

13. Halatek, T., Sinczuk-Walczak, H., Rabieh, S., Wasowicz, W. (2009) Association between occupational exposure to arsenic and neurological, respiratory and renal effects. Toxicol. Appl. Pharmacol. 239, 193-199.

14. Hughes, M. F. (2002) Arsenic toxicity and potential mechanisms of action. Toxicol. Lett. 133, 1-16.

15. Javed, H., Khan, M. M., Ahmad, A., Vaibhav, K., Ahmad, M. E., Khan, A., Ashafaq, M., Islam, F., Siddiqui, M. S., Safhi, M. M., Islam, F. (2012) Rutin prevents cognitive impairments by ameliorating oxidative stress and neuroinflammation in rat model of sporadic dementia of Alzheimer type. Neuroscience 210, 340-352.

16. Jomova, K., Jenisova, Z., Feszterova, M., Baros, S., Liska, J., Hudecova, D., Rhodes, C. J., Valko, M. (2011) Arsenic: toxicity, oxidative stress and human disease. J. Appl. Toxicol. 31, 95-107.

17. Kandel, E. R., Schwartz, J. H. (1985) Principles of Neural Science. Elsevier, New York.

18. Kim, K. H., Lee, K. W, Kim, D. Y., Park, H. H., Kwon, I. B., Lee, H. J. (2005) Optimal recovery of high-purity rutin crystals from the whole plant of Fagopyrum esculentum Moench (buckwheat) by extraction, fractionation, and recrystallization. Biores. Technol. 96, 1709-1712.

19. Le Quesne, P. M., McLeod, J. G. (1977) Peripheral neuropathy following a single exposure to arsenic. Clinical course in four patients with electrophysiological and histological studies. J. Neurol. Sci. 32, 437-451.

20. Lindberg, A. L., Goessler, W., Gurzau, E., Koppova, K., Rudnai, P., Kumar, R., Fletcher, T., Leonardi, G., Slotova, K., Gheorghiuc, E., Vahter, M. (2006) Arsenic exposure in Hungary, Romania and Slovakia. J. Environ. Monit. 8, 203-208. 
21. Maggi, C. A., Meli, A. (1986): Suitability of urethane anesthesia for physiopharmacological investigations in various systems. Part 1: General considerations. Experientia 42, 109-114.

22. Mishra, D., Flora, S. J. S. (2008) Quercetin administration during chelation therapy protects arsenicinduced oxidative stress in mice. Biol. Trace Elem. Res. 122, 137-147.

23. Nordstrom, D. K. (2002) Public health. Worldwide occurrences of arsenic in ground water. Science 296, 2143-2145.

24. Omololu, P. A., Rocha, J. B. T., Kade, I. J. (2011) Attachment of rhamnosylglucoside on quercetin confers potent iron-chelating ability on its antioxidant properties. Exp. Toxicol. Pathol. 63, 249-255.

25. Pandey, K. B., Rizvi, S. I. (2009) Plant polyphenols as dietary antioxidants in human health and disease. Oxidative Med. Cell. Longevity 2, 270-278.

26. Papp, A., Pecze, L., Vezér, T. (2004) Dynamics of central and peripheral evoked electrical activity in the nervous system of rats exposed to xenobiotics. Centr. Eur. J. Occup. Envir. Med. 10, 52-59.

27. Park, S. E., Sapkota, K., Choi, J. H., Kim, M. K., Kim, Y. H., Kim, K. M., Kim, K. J., Oh, H. N., Kim, S. J., Kim, S. (2014) Rutin from Dendropanax morbifera Leveille protects human dopaminergic cells against rotenone induced cell injury through inhibiting JNK and p38 MAPK signaling. Neurochem. Res. 39, 707-718.

28. Parvez, F., Wasserman, G. A., Factor-Litvak, P., Liu, X., Slavkovich, V., Siddique, A. B., Sultana, R., Sultana, R., Islam, T., Levy, D., Mey, J. L., van Geen, A., Khan, K., Kline, J., Ahsan, H., Graziano, J. H. (2011) Arsenic exposure and motor function among children in Bangladesh. Environ. Health Perspect. 119, 1665-1670.

29. Ratnaike, R. N. (2003) Acute and chronic arsenic toxicity. Postgrad. Med. J. 79, 391-396.

30. Rodríguez, V. M., Jiménez-Capdeville, M. L., Giordano, M. (2003) The effects of arsenic exposure on the nervous system. Toxicol. Lett. 145, 1-18.

31. Sárközi, K., Krisch, J., Papp, A. (2013) Effect of green tea on arsenic toxicity in rats. In: Galbács, G. (ed.) Proceedings of the 19th International Symposium on Analytical and Environmental Problems, Szeged, pp. 261-264.

32. Sárközi, K., Nagy, V., Papp, A., Tombácz, E., Szabó, A. (2013) The effect of three natural antioxidants on the general and nervous system toxicity of manganese nanoparticles in rats. Centr. Eur. J. Occup. Environ. Med. 19, 31-42.

33. Schulz, H., Nagymajtényi, L., Institóris, L., Papp, A., Siroki, O. (2002) A study on behavioral, neurotoxicological, and immunotoxicological effects of subchronic arsenic treatment in rats. J. Toxicol. Environ. Health. 65, 1181-1193.

34. Stavric, B. (1994) Role of chemopreventers in human diet. Clin. Biochem. 27, 319-332.

35. Szabó, A., Lengyel, Z., Lukács, A., Papp, A. (2006) Studies on the neurotoxicity of arsenic in rats in different exposure timing schemes. Trace Elem. Electrol. 23, 193-196.

36. Vahidnia, A., van der Voet, G. B., de Wolff, F. A. (2007) Arsenic neurotoxicity - A review. Hum. Exp. Toxicol. 26, 823-832.

37. Vezér, T., Kurunczi, A., Náray, M., Papp, A., Nagymajtényi, L. (2007) Behavioral effects of subchronic inorganic manganese exposure in rats. Am. J. Ind. Med. 50, 841-852.

38. Yadav, R. S., Sankhwar, M. L., Shukla, R. K., Chandra, R., Pant, A. B., Islam, F., Khanna, V. K. (2009) Attenuation of arsenic neurotoxicity by curcumin in rats. Toxicol. Appl. Pharmacol. 240, 367-376.

39. Zafrilla, P., Morillas, J. M., Rubio-Perez, J. M., Villar, E. C. (2009) Ingredients for functional drinks in neurodegenerative diseases: a review. Natural Products Comm. 4, 1-22. 